\title{
Article \\ Numerical Training Videos and Early Numerical Achievement: A Study on 3-Year-Old Preschoolers
}

\author{
Alessandro Cuder, Marta Vidoz, Chiara De Vita (D), Sandra Pellizzoni and Maria Chiara Passolunghi *
}

check for

updates

Citation: Cuder, A.; Vidoz, M.;

De Vita, C.; Pellizzoni, S.

Passolunghi, M.C. Numerical

Training Videos and Early Numerical

Achievement: A Study on 3-Year-Old

Preschoolers. Brain Sci. 2022, 12, 88.

https://doi.org/10.3390/

brainsci12010088

Academic Editors: Liane Kaufmann,

Laura Zamarian, Guilherme Wood

and Elise Klein

Received: 7 December 2021

Accepted: 7 January 2022

Published: 11 January 2022

Publisher's Note: MDPI stays neutral with regard to jurisdictional claims in published maps and institutional affiliations.

Copyright: () 2022 by the authors. Licensee MDPI, Basel, Switzerland. This article is an open access article distributed under the terms and conditions of the Creative Commons Attribution (CC BY) license (https:// creativecommons.org/licenses/by/ $4.0 /)$.

\author{
Department of Life Sciences, University of Trieste, 34128 Trieste, Italy; alessandro.cuder@phd.units.it (A.C.); \\ martavidoz@gmail.com (M.V.); chiaradv@hotmail.it (C.D.V.); spellizzoni@units.it (S.P.) \\ * Correspondence: passolu@units.it; Tel.: +39-0405588866
}

\begin{abstract}
Early numerical abilities predict later math achievement and could be improved in children by using various training methods. As the literature on the use of training videos to develop numerical abilities is still surprisingly scant, the aim of the present study was to test the efficacy of a numerical training video on the development of counting and number line knowledge in 3-year-old preschoolers. Far transfer effects to cardinality and working memory were also examined. The study involved 86 children randomly assigned to two intervention groups: a numerical training group exposed to videos on counting and number lines; and a control group exposed to videos on colors and animal names in a foreign language. After the video training, there was an improvement in the numerical training group's counting skills, but not in their number line knowledge, and this improvement persisted six months later. The numerical training group also showed a far-transfer enhancement of cardinality six months after the intervention. Based on our results, numerical training videos could be effective in helping to enhance early numeracy skills in very young preschoolers.
\end{abstract}

Keywords: learning; mathematics; preschoolers; training; videos; counting; cardinality

\section{Introduction}

In an increasingly technological and numeracy-based society, children's mathematical schooling is fundamental to their long-term general development. The literature suggests that individuals' numerical abilities predict their future educational, occupational, and financial success, positively influencing outcomes such as employment [1,2], salary size [3], and socioeconomic status $[4,5]$. Although numeracy is a strong predictor of success in life, several studies have demonstrated that around $20 \%$ of students show low numerical skills, and from $4 \%$ to $14 \%$ of children and adolescents exhibit a learning deficit in at least one mathematical area [6-9].

Given the impact of mathematical competence on individuals and societies, it seems crucial to assess numerical abilities from a very early age in order to take action to prevent potential learning difficulties in the sphere of mathematics, from pre-school onwards. Several studies have suggested that mathematical learning is sustained by a set of general and specific cognitive skills, defined as 'precursors' [10-13].

\subsection{Domain-Specific Precursors}

Domain-specific numerical skills specifically predict future mathematical performance [14-16]. They include counting, or the ability to establish a one-to-one relationship between objects in a set and their numerical representations [17,18]. Learning to count has been found to play a fundamental part in sustaining later mathematical learning in both primary [19-21] and secondary school [22]. Typically, this skill begins to develop from the age of two and, although children are able to recite the words in order, they do not understand that the aim of counting is the quantification [23-26]. Another domain-specific skill, related to counting, is the ability to understand cardinality, i.e., that the last word 
counted stands for the total number of items in the counted set [23,27-29]. Implicit in this ability there is the understanding that number words correspond to unique and specific quantities [30], which is a strong predictor of later mathematical achievement [27,31-33]. Literature shows that cardinality skill develops from the third to the fourth year of age following the full acquisition of the counting process $[24,25,34]$. Another domain-specific precursor is number line knowledge, which refers to the ability to form a mental representation of a graduated line on which each number corresponds to a position [35,36]. This skill seems to be related to a wide range of numerical abilities [37] and, as suggested by a recent meta-analysis [38], it is recognized as a strong predictor of mathematical learning.

\subsection{Domain-General Precursors}

While domain-specific abilities are specifically associated with mathematical learning, domain-general skills relate to abilities that predict children's academic success in other school subjects as well $[39,40]$. One domain-general skill is working memory (WM), which seems to influence academic success in a number of disciplines. WM is a cognitive system comprising several subsystems that handle both verbal and visuospatial information [41-44]. Additionally, there is a distinction between high-control WM processes that require concurrent storage, processing, and effortful mental activity, and lowcontrol WM processes involved in the retainment of small amounts of information that are subsequently recalled $[45,46]$. Literature shows that WM is associated with children's performance in calculus, problem solving and mathematics [47-49]. Visuo-spatial WM is needed to acquire a basic knowledge of numbers [46,50,51], while verbal WM seems to be more useful later on, for the acquisition of more complex mathematical abilities [46,47,51], such as math fluency and word problem solving [20,52].

\subsection{Numeracy Training Studies}

Having established the predictive role of domain-specific and domain-general precursors, research has focused on developing interventions to boost the skills associated with mathematical achievement. Few studies on training measures to enhance numerical abilities have been conducted on 3-year-olds to date (e.g., [53]), but the literature suggests that exposing preschool children to suitably-designed materials can enhance abilities linked to mathematical learning. To give some examples, domain-specific training has reportedly been successful in promoting numerical skills such as counting [53-58], cardinality [28,29], and number line knowledge $[53,55,59]$. As regards the training effectiveness for age groups, interventions on counting and cardinality seem to have provided positive outcomes already at three years of age $[28,53]$, while number line trainings have been proved particularly useful in the last years of preschool $[55,58,59]$. Mixed results were obtained, on the other hand, with interventions addressing domain-general WM skills $[54,56,60,61]$. According to recent meta-analyses [61,62], WM training interventions seem to produce short-term effects that fail to generalize to arithmetical skills. Most of preschool WM interventions available in the literature were conducted on samples who had an average age ranging from four [63] to five years $[54,56,64]$. It is still unclear whether WM abilities can be enhanced at an early age, however, and this possibility is worth exploring.

Domain-specific or domain-general training studies have traditionally been based on face-to-face interventions (especially for younger children), with operators engaging in educational activities with a group of children, or else on a computer-based modality for single individuals. These types of training promote the active participation of the children involved, in both computer-based activities (e.g., [57,59]) and small group activities (e.g., $[53,58,65])$. Past interventions targeting preschoolers usually proposed content embedded in playful activities requiring some degree of numerical processing (e.g., $[54,56,65])$. For instance, board games usage is commonly reported in literature for developing counting and number line abilities because it exposes children to the order of numbers and numerical quantities [66]. Other studies developed entertaining videogames in which numerical skills were trained in the context of playful challenges bringing improvements in 
counting, cardinality and number line knowledge [57,59]. These interventions commonly lasted from two to five weeks with meetings scheduled twice a week.

Nowadays, children can be passively exposed via child-friendly apps on tablets or mobile phones to a variety of videos developed to entertain or promote learning. According to a survey conducted on parents in the US [67], children from 2 to 4 years of age were exposed to screens for about two and half hours a day. Nearly three in four respondents $(73 \%)$ reported that their children's screen time was spent mainly watching television and videos, with a large amount of the time $(37 \%)$ occupied by videos on online platforms (see also [68]). Despite such a pervasive trend, little is known about the real effects of exposing children to educational videos in terms of their content acquisition. Part of the literature suggests that video learning could be difficult for certain age groups [69]. In particular, some studies have shown that very young children (from the first to the second year of age) can exhibit deficit in learning through videos and transferring the assimilated knowledge in different testing contexts [70-73]. However, the effects of exposure to videos with numerical content on the development of preschoolers' numerical skills remain unclear.

The limited literature on the topic dates back to the early 1970s, when the focus was on assessing the educational impact of TV programs (e.g., [74,75]). An example is the TV program "Sesame Street", popular in the US, which targeted preschool children in an effort to boost several early life skills. Numerous studies found exposure to this show associated with positive effects on linguistic, mathematical, and everyday living skills [70-72,76]. These investigations commonly lasted for several months and preschoolers were shown educational content embedded in several episodes of Sesame Street at home or at school. Progress was then assessed with different tools and compared to the viewing time reported by parents and teachers. A meta-analysis on several such studies and reports from various countries also confirmed that watching Sesame Street was associated with positive outcomes on linguistic and mathematical abilities in children with different cultural backgrounds [77]. Alongside research generally examining the educational effectiveness of TV programs, there are studies that investigated the role of crucial variables in the learning of numerical skills from watching videos. For instance, Lauricella and colleagues [78] found that exposure to numerical videos had positive effects on children's seriation abilities providing the characters were perceived as meaningful. Another study by Aladé and colleagues [79] found that a video-based training could enhance measurement skills and promote far-transfer effects on dissimilar tasks. Schroeder and Kirkorian [80] also demonstrated that children perform better on quantity discrimination when they are passively exposed to numerical videos than when interfacing with interactive applications. In short, although preschoolers tend to watch videos every day, at home and elsewhere $[67,68]$, the literature on passive learning through video exposure is still surprisingly scant.

\subsection{The Present Study}

In the light of the above considerations, the aim of the present study was to investigate the effects of exposure to videos with numerical content on the development of early numerical abilities in a sample of 3-year-old preschoolers. Most of the previously-mentioned studies used face-to-face training and interactive programs to improve early numerical abilities, and none examined the effects of exposure to numerical videos on domain-specific abilities (such as counting, cardinality, and number line knowledge) and domain-general abilities (such as WM) at the same time. Given how online video consumption is increasing among today's preschoolers [67,68], this trend could be exploited to convey evidence-based interventions employing commonly-used devices. For the present study, we therefore prepared numerical training videos, and assessed their impact on the development of early numerical skills (i.e., counting, cardinality and number line knowledge) and low-control WM abilities. First, we hypothesized that counting ability could be fostered through passive exposure to videos showing children the enumeration process, as reported elsewhere (e.g., [56,58]). Second, we hypothesized that exposure to numerical videos could enhance number line knowledge, in line with reports that a correct linear representation of num- 
bers could be developed by exposing children to the spatial arrangement of numbers and quantities on a straight line (e.g., [65]). We also expected counting video training to have an effect on children's understanding of cardinality, as evidence suggests that counting is a precursor to cardinality [81,82]. Finally, we explored the effects of numerical video training on the development of low-control WM skills, an issue on which the literature is inconsistent $[54,56,60,61]$ : we did not expect our numerical training videos to improve the children's WM.

\section{Materials and Methods}

\subsection{Participants}

The initial sample selected for this study included 91 preschoolers, 3 years of age, attending nursery schools in Northeast Italy. With the schools' approval, parents were contacted to obtain their consent to their children's participation. The parents of 5 children refused, so the final sample in the pretest phase consisted of 86 children (40 females; $\mathrm{M}_{\mathrm{age}}=43.3$ months, $\mathrm{SD}_{\text {age }}=3.21$ ). Participants were randomly assigned to one of two groups: a numerical training group $\left(n=43 ; \mathrm{M}_{\mathrm{age}}=42.9\right.$ months, $\left.\mathrm{SD}_{\text {age }}=2.95\right)$; and an active control group $\left(n=43 ; \mathrm{M}_{\mathrm{age}}=43.7\right.$ months, $\left.\mathrm{SD}_{\mathrm{age}}=3.43\right)$. Missing data and the outliers were handled with listwise deletion rather than run imputation methods to avoid biased score estimations. In the pretest and post-test evaluation one participant $(n=1)$ was removed as an outlier because of his emigrational background and his difficulties to comprehend the verbal WM task. At the follow-up, 12 participants were removed from the analysis ( $n=3$ due to outlier scores in numeracy abilities evaluation and $n=9$ due to dropout from the study). All other participants attended all the training sessions. All participants were Caucasian and their socio-economic status (judging from the school records) was middle class. A written informed consent form was signed by each child's parents before they took part in the study. Children were asked for their verbal consent to their participation in the activities prior to the assessment and training sessions. The study was conducted in accordance with the Declaration of Helsinki, the ethical guidelines of the Italian Association of Psychology, and the ethical code of the Italian Register of Professional Psychologists.

\subsection{Procedure}

The study was conducted in four phases.

\subsubsection{Pretest Phase}

In the pretest phase, the children were tested on their domain-specific and domaingeneral abilities in two sessions (20 min each). Vocabulary knowledge and attentional tasks were also administered as control measures to check for any differences between the two groups' cognitive levels. Counting ability, understanding of cardinality, and number line knowledge were used to assess their early numerical (domain-specific) skills, and WM was assessed as a domain-general ability.

\subsubsection{Training Phase}

In the subsequent training phase, participants were exposed to the numerical training or active control videos in small groups ( 3 to 5 children). The training sessions were held twice a week. Twelve sessions were scheduled, during each of which children were shown two videos on the same topic. The active control group was shown videos about colors and animal names.

\subsubsection{Posttest Phase}

In a third, posttest phase, the children were tested on their early numerical abilities and WM. 


\subsubsection{Follow-Up Phase}

Five months later, at the beginning of the second year of nursery school we added a follow-up assessment and tested children on counting ability, cardinality understanding, and number line knowledge only.

\subsection{Pretest Control Measures}

\subsubsection{Receptive Vocabulary}

WPPSI-III [82] was used to assess the children's word knowledge. They were shown 38 sheets of paper with 4 printed images and asked to indicate which of the four images corresponded to the word the researcher was saying. The task was interrupted after 5 consecutive errors. The total score was the sum of the correctly recognized images and could range from 0 to 38 .

\subsubsection{Selective Attention}

A task was adapted from an attention subtest in the BVN 12-18 battery [83]. The test involved watching a video in which several visual stimuli were randomly presented on a screen at a rate of one picture per second. The children were asked to clap their hands whenever a target stimulus (e.g., the sun) appeared on the screen. The total score, calculated as the sum of correctly identified target stimuli, could range from 0 to 20 .

\subsubsection{Visuospatial Low-Control WM}

The task used to assess visuospatial WM involved the child remembering a toy frog's movements within a $3 \times 3$ matrix, touching the cells previously indicated by the researcher [84]. The test included four levels of increasing difficulty, with two sets of movements for each level. It was interrupted when a child made two mistakes on the same level of difficulty. Scores were calculated as the sum of the positions correctly recalled. The total score could range from 0 to 8 .

\subsubsection{Verbal Low-Control WM}

This task involved presenting lists of commonly-used words and asking the child to repeat each list immediately after hearing it, recalling the words in the same order of presentation [84]. The test included four levels of difficulty for a total of eight tests. The task was interrupted when a child made two mistakes on the same level of difficulty. Scores were calculated as the sum of the words correctly recalled in the right order. The total score could range from 0 to 8 .

\subsection{Pretest and Posttest Numeracy Measures}

\subsubsection{Counting}

Counting skills were assessed with a task adapted from an enumeration subtest in the Numerical Intelligence Battery [85]. The children were asked to count forwards from 1 to 20 and their total score corresponded to the highest number counted correctly.

\subsubsection{Cardinality}

A task adapted from Le Corre and Carey [25] was used to assess the children's understanding of cardinality. They were randomly presented with nine cards showing from 1 to 9 different objects. For each card, they were asked first to count the objects, then to say how many objects there were on the card. They scored one point if they correctly counted the objects and answered the examiner's question correctly without needing to start the counting process again. Scores could range from 0 to 9 .

\subsubsection{Number Line Knowledge}

A task adapted from Laski and Siegler [86] was used. The children were shown a line with five equally-spaced notches and the numbers " 1 " and " 5 " at the ends. They were then shown random numbers from 1 to 5 and asked to place them along the number line. 
They scored one point for each number correctly placed on the line. Total scores in this task could range from 0 to 5 .

\subsection{Characteristics of the Intervention}

\subsubsection{Numerical Training Group Intervention}

We first established the features the videos needed to have to suit the purposes of our intervention. We wrote video scripts with two puppet characters (a bear and a tiger) playing games that involved counting and number lines, with numbers ranging from 1 to 10. For instance, the videos that focused on counting involved enumerating objects or simply pronouncing numerical sequences, while the number line videos presented number symbols or sets of objects arranged along a graduated number line. The scenes were recorded with a reflex camera (Nikon D3100, with a Nikon 18-55 mm f3.5 lens), then the raw videos were dubbed and edited. This procedure was used to create six videos, three on counting and three on number lines (see Table 1).

Table 1. Topic, duration in minutes and content description of the training videos.

\begin{tabular}{|c|c|c|c|}
\hline \multicolumn{4}{|c|}{ Training Videos } \\
\hline & Topic & Duration in Minutes & Content Description \\
\hline 1 & Counting & 4 & $\begin{array}{l}\text { Characters were involved in counting activities from } 1 \text { to } 9 . \\
\text { Example: puppets had to count mushrooms' white dots. }\end{array}$ \\
\hline 2 & Counting & 4 & $\begin{array}{l}\text { Characters were involved in counting activities from } 1 \text { to } 10 . \\
\text { Example: puppets had to count fruit sets that were placed } \\
\text { inside a case. }\end{array}$ \\
\hline 3 & Counting & 4 & $\begin{array}{l}\text { Characters were involved in counting activities from } 1 \text { to } 10 \text {. } \\
\text { Example: puppets counted candies placed inside a } \\
\text { plastic bottle. }\end{array}$ \\
\hline 4 & Number line & 4 & $\begin{array}{l}\text { Characters were involved in arranging numbers on a } \\
\text { number line from } 1 \text { to } 5 \text {. Example: puppets had to sort some } \\
\text { jars with numbers printed on them in a number line. }\end{array}$ \\
\hline 5 & Number line & 4 & $\begin{array}{l}\text { Characters were involved in arranging numbers on a } \\
\text { number line from } 1 \text { to } 5 \text {. Example: puppets had to sort } \\
\text { digits on a number line. }\end{array}$ \\
\hline 6 & Number line & 4 & $\begin{array}{l}\text { Characters were involved in arranging numbers on a } \\
\text { number line from } 1 \text { to } 10 \text {. Example: puppets had to sort ten } \\
\text { stones with digits printed on them on a number line. }\end{array}$ \\
\hline \multicolumn{4}{|c|}{ Active Control Group Videos } \\
\hline & Topic & Duration in Minutes & Content Description \\
\hline 1 & Colors & 4 & $\begin{array}{l}\text { Characters were involved in naming colors. Example: } \\
\text { puppets had to name the colors of flower's petals (red, blue, } \\
\text { green, yellow). }\end{array}$ \\
\hline 2 & Colors & 4 & $\begin{array}{l}\text { Characters were involved in naming colors. Example: } \\
\text { puppets had to name the colors of fruits (red, orange, green, } \\
\text { purple, yellow). }\end{array}$ \\
\hline 3 & Colors & 4 & $\begin{array}{l}\text { Characters were involved in naming colors. Example: } \\
\text { puppets had to name the colors of candies (red, orange, } \\
\text { purple, yellow). }\end{array}$ \\
\hline 4 & Animals & 4 & $\begin{array}{l}\text { Characters were involved in naming animals. Example: } \\
\text { puppets had to name jungle animals (tiger, monkey, } \\
\text { elephant, parrot, giraffe). }\end{array}$ \\
\hline 5 & Animals & 4 & $\begin{array}{l}\text { Characters were involved in naming animals. Example: } \\
\text { puppets had to name wood animals (wolf, owl, deer, fox). }\end{array}$ \\
\hline 6 & Animals & 4 & $\begin{array}{l}\text { Characters were involved in naming animals. Example: } \\
\text { puppets had to name sea animals (whale, shrimp, } \\
\text { turtle, shark). }\end{array}$ \\
\hline
\end{tabular}




\subsubsection{Control Group Intervention}

Videos for the control group were selected on the YouTube platform, choosing among those dubbed in a foreign language (English) and suitable for 3-year-old preschoolers (e.g., videos about color names, see Table 1). These videos were edited to match the duration and resolution of our numerical training videos, obtaining six videos, three about colors and three about animals. We used foreign language videos because we decided to offer contents, unrelated to numerical activities, which could be perceived by children as entertaining and engaging, with the same educational value of numerical training videos.

\section{Results}

Table 2 shows the descriptive and univariate test results (from MANOVA) for the two groups.

Table 2. Reliabilities (R), mean scores (M), standard deviations (SD), minimum (Min.) and maximum (Max.) scores, and univariate test results ( $F$ and $F_{\text {gains }}$ from MANOVA) in the different measures for the two groups at the three time points (pretest, posttest, follow-up). ${ }^{* *} p<0.01,{ }^{* * *} p<0.001$.

\begin{tabular}{|c|c|c|c|c|c|c|c|c|}
\hline \multicolumn{9}{|c|}{ Pretest Assessment } \\
\hline \multirow[t]{2}{*}{ Measures } & \multirow[t]{2}{*}{$\mathbf{R}$} & \multicolumn{2}{|c|}{$\begin{array}{l}\text { Training Group } \\
\quad(n=42)\end{array}$} & \multicolumn{2}{|c|}{$\begin{array}{l}\text { Control Group } \\
\quad(n=43)\end{array}$} & \multirow{2}{*}{ Min. } & \multirow{2}{*}{ Max. } & \multirow[t]{2}{*}{$F$} \\
\hline & & $\mathbf{M}$ & SD & $\mathbf{M}$ & SD & & & \\
\hline Receptive vocabulary & 0.94 & 10.7 & 3.24 & 11.3 & 3.07 & 1 & 17 & 0.79 \\
\hline Selective attention & 0.92 & 16.2 & 4.30 & 16.2 & 2.85 & 5 & 20 & 0.01 \\
\hline Visuospatial WM & 0.80 & 2.44 & 1.18 & 2.51 & 1.03 & 0 & 4 & 0.12 \\
\hline Verbal WM & 0.89 & 3.02 & 0.87 & 2.88 & 0.54 & 0 & 4 & 0.80 \\
\hline Counting & 0.83 & 7.84 & 5.19 & 8.81 & 4.47 & 0 & 20 & 1.15 \\
\hline Cardinality & 0.84 & 2.30 & 2.88 & 3.02 & 2.64 & 0 & 9 & 1.97 \\
\hline Number line knowledge & 0.75 & 1.40 & 1.14 & 1.67 & 1.32 & 0 & 5 & 1.42 \\
\hline \multicolumn{9}{|c|}{ Post-test Assessment } \\
\hline \multirow[t]{2}{*}{ Measures } & \multirow[t]{2}{*}{$\mathbf{R}$} & \multicolumn{2}{|c|}{$\begin{array}{l}\text { Training Group } \\
\quad(n=42)\end{array}$} & \multicolumn{2}{|c|}{$\begin{array}{c}\text { Control Group } \\
(n=43)\end{array}$} & \multirow[t]{2}{*}{ Min. } & \multirow[t]{2}{*}{ Max. } & \multirow[t]{2}{*}{$F_{\text {gains }}$} \\
\hline & & $\mathbf{M}$ & SD & $\mathbf{M}$ & SD & & & \\
\hline Visuospatial WM & 0.80 & 2.67 & 0.94 & 3.09 & 0.97 & 0 & 5 & 2.03 \\
\hline Verbal WM & 0.89 & 3.38 & 0.76 & 3.12 & 0.50 & 0 & 5 & 0.73 \\
\hline Counting & 0.83 & 12.5 & 4.41 & 8.51 & 4.59 & 0 & 20 & $25.8^{* * *}$ \\
\hline Cardinality & 0.84 & 4.58 & 3.51 & 5.02 & 2.76 & 0 & 9 & 0.19 \\
\hline Number line knowledge & 0.75 & 1.65 & 1.15 & 1.58 & 1.18 & 0 & 5 & 1.16 \\
\hline \multicolumn{9}{|c|}{ Follow-Up Assessment } \\
\hline \multirow[t]{2}{*}{ Measures } & \multirow[t]{2}{*}{$\mathbf{R}$} & \multicolumn{2}{|c|}{$\begin{array}{l}\text { Training Group } \\
\quad(n=33)\end{array}$} & \multicolumn{2}{|c|}{$\begin{array}{l}\text { Control Group } \\
\quad(n=41)\end{array}$} & \multirow[t]{2}{*}{ Min. } & \multirow[t]{2}{*}{ Max. } & \multirow[t]{2}{*}{$F_{\text {gains }}$} \\
\hline & & $\mathbf{M}$ & SD & $\mathbf{M}$ & SD & & & \\
\hline Counting & 0.83 & 14.2 & 4.86 & 10.8 & 5.81 & 0 & 20 & $14.9^{* * *}$ \\
\hline Cardinality & 0.84 & 6.85 & 2.76 & 5.07 & 2.99 & 0 & 9 & $11.5^{* *}$ \\
\hline Number line knowledge & 0.75 & 1.24 & 0.94 & 1.71 & 1.19 & 0 & 5 & 0.05 \\
\hline
\end{tabular}

\subsection{Pretest Assessment}

To check for any differences between the two groups at the baseline, we ran a multivariate analysis of variance (MANOVA) with group (numerical training group vs control 
group) as a fixed factor and pretest measures (receptive vocabulary, selective attention, visuospatial WM, verbal WM, counting, cardinality and number line knowledge) as dependent variables. A measure of effect size was used to compare the differences between the groups' pretest scores. Cohen's criteria [87] were used to classify the effect size: small effect $\left(\eta_{\mathrm{p}}{ }^{2}=0.01\right)$, medium effect $\left(\eta_{\mathrm{p}}{ }^{2}=0.06\right)$, large effect $\left(\eta_{\mathrm{p}}{ }^{2}=0.14\right)$. Effect sizes (Cohen's $\left.d\right)$ for pairwise comparisons are also reported; small effect $d=0.20$; medium effect $d=0.50$; large effect $d=0.80$.

The results of the MANOVA showed no significant effect of group (Wilks' Lambda $=0.941$, $\left.F(7,77)=0.69, p=0.678, \eta_{p}{ }^{2}=0.974\right)$, meaning that the two groups did not differ statistically in the pretest phase. Univariate tests showed no statistically significant difference in their receptive vocabulary $F(1,83)=0.79, p=0.376, \eta_{\mathrm{p}}{ }^{2}=0.009$, selective attention $F(1,83)=0.01$, $p=0.958, \eta_{\mathrm{p}}^{2}=0.000$, visuospatial WM $F(1,83)=0.12, p=0.732, \eta_{\mathrm{p}}{ }^{2}=0.001$, verbal WM $F(1,83)=0.80, p=0.374, \eta_{\mathrm{p}}{ }^{2}=0.010$, counting $F(1,83)=1.15, p=0.286, \eta_{\mathrm{p}}{ }^{2}=0.014$, cardinality $F(1,83)=1.97, p=0.164, \eta_{p}{ }^{2}=0.023$ or number line knowledge $F(1,83)=1.42, p=0.237$, $\eta_{\mathrm{p}}{ }^{2}=0.017$. In short, there were no statistically significant differences between the two groups at pretest.

\subsection{Posttest Assessment}

We calculated the gains (posttest minus pretest) in the children's early numerical abilities (counting, cardinality, number line knowledge) and WM scores. This analytical strategy-comparing gains from pre- and post-training assessments-had been used in several previous studies (e.g., [56,88-90]). We ran a MANOVA using group as the fixed factor and gain in scores as dependent variables. We also applied Bonferroni's adjusted posthoc pairwise comparisons of the gains. To compare the gains made between the two groups, $\eta_{\mathrm{p}}{ }^{2}$ and effect sizes (Cohen's $d$ /Hedges' $g$ ) were used for post-hoc pairwise comparisons.

The results of the MANOVA showed a significant main effect of group (Wilks' Lambda $\left.=0.725, F(5,80)=6.07, p<0.001, \eta_{p}^{2}=0.275\right)$, suggesting statistically significant differences between the two groups at posttest. The univariate analysis showed a statistically significant difference between the groups for counting $F(1,84)=25.8, p<0.001$, $\eta_{\mathrm{p}}{ }^{2}=0.235$, pointing to different effects of the two interventions. Bonferroni's adjusted pairwise post-hoc comparisons indicated a significant effect of the numerical training on counting ability compared with the control group $\left(\mathrm{M}_{\text {diff }}=5.00, p<0.001, d=1.095\right)$. No statistically significant difference emerged between the groups for visuospatial WM $F(1,84)=2.03$, $p=0.158, \eta_{\mathrm{p}}{ }^{2}=0.024$, verbal WM $F(1,84)=0.73, p=0.39, \eta_{\mathrm{p}}{ }^{2}=0.009$, cardinality $F(1,84)=0.19$, $p=0.661, \eta_{\mathrm{p}}{ }^{2}=0.002$, or number line knowledge $F(1,84)=1.16, p=0.285, \eta_{\mathrm{p}}{ }^{2}=0.014$.

\subsection{Follow-Up Assessment}

We calculated the gains (follow-up minus pretest) from pretest to follow-up in the children's counting, cardinality, and number line knowledge scores, conducting a MANOVA with group as a fixed factor and gains in scores as dependent variables.

The results showed a significant main effect of group (Wilks' Lambda $=0.737$, $\left.F(3,70)=8.31, p<0.001, \eta_{\mathrm{p}}{ }^{2}=0.263\right)$ suggesting statistically significant differences between the two groups. The univariate analysis showed statistically significant differences for counting $F(1,72)=14.9, p<0.001, \eta_{\mathrm{p}}{ }^{2}=0.171$ and cardinality $F(1,72)=11.5, p=0.001$, $\eta_{\mathrm{p}}{ }^{2}=0.138$, pointing to different effects of the two interventions. Compared with the control group, Bonferroni's adjusted pairwise post-hoc comparisons indicated long-term enhancement effects of the numerical training on the children's counting ability $\left(\mathrm{M}_{\text {diff }}=4.237\right.$, $p<0.001, d=0.9197)$, and understanding of cardinality $\left(\mathrm{M}_{\text {diff }}=2.661, p=0.001, d=0.791\right)$. No statistically difference emerged between the numerical training and control groups on number line knowledge $F(1,72)=0.05, p=0.814, \eta_{\mathrm{p}}{ }^{2}=0.001$.

To sum up, we found a statistically significant improvement in the counting task at posttest in the numerical training group by comparison with the control group. Other differences in the two groups' gains on cardinality, number line knowledge and WM were not statistically significant. We also found differences at the follow-up comparison between 
the two groups, which were significant for counting and cardinality, but not for number line knowledge.

\section{Discussion}

The aim of the present study was to assess the effectiveness of a passive video-based training for promoting specific numerical abilities in 3-year-old children. After 12 sessions of exposure, our analysis of posttest performance gains showed enhanced counting skills in the numerical training group compared with the control group. This outcome replicates previous study findings on the positive effect on counting skills of various types of stimulation, such as board games (e.g., [65]) and computer-based activities (e.g., [57]). The significant gains seen in the numerical training group's counting abilities also persisted five months later, demonstrating long-lasting effects of the intervention. This could be because the training videos were designed to offer considerable benefits in a development age when children are predisposed to acquiring counting skills [17,91,92]. Passive viewing of numerical training videos could therefore be a good way to enhance counting abilities in 3-year-olds.

On number line knowledge, our numerical training group did not perform significantly better than the control group, neither at posttest nor at follow-up. This outcome contrasts with other reports of improvements gained by exposing children to number line training interventions $[53,55,56,59]$. One reason for our findings could lie in our sample's age, as the children may have been too young to benefit from the training. In fact, a recent study [93] found that preschool children performed poorly in even the simplest number line estimates and, unsurprisingly, number line training interventions described in the literature were conducted on children more than 3 years old $[53,55,59]$. Passive video stimulation might also be inadequate for developing number line knowledge. Future intervention studies could test other methods that have proved successful in the literature, such as board games (e.g., [55]) and computer-based activities (e.g., [59]).

Potential far transfer effects on cardinality and WM were also examined. As concerns the children's understanding of cardinality, the numerical training group's gains did not differ significantly from the control group's at posttest. This result is consistent with previous studies involving training programs that used counting to enhance children's understanding of cardinality $[28,29]$. On the other hand, our numerical training group showed an improvement in this area, compared with the control group, at the follow-up five months later. This was probably a far transfer effect of their counting training, which could have helped them to develop stronger cardinality-related skills. The literature has consistently shown that number list knowledge and counting skills are fundamental to understanding the quantities associated with number words $[23,30,81]$.

No far transfer effects were seen on visuospatial or verbal low-control WM. This is in line with previous research (e.g., [56,60]) focusing on WM interventions, which generated mixed results $[54,56,60,61]$, and any short-term effects failed to generalize to numerical abilities $[61,62]$. Our results extend the evidence on the inability of numerical training videos to influence WM in young preschoolers.

\section{Limitations and Future Directions}

More research is needed to overcome the limitations of the present study. For a start, we were unable to distinguish between the effects of counting and number line training videos because we exposed the children in the numerical training group to both types of material. Future studies should replicate our results while separately examining the effects of training these and other early numerical abilities. We also used only one training modality. Moreover, we should recognize that cardinality and number line tasks could have been too challenging for some children, especially at the pretest assessment. This could have biased our results lowering discriminant power of instruments or affecting children motivation in executing proposed tasks. Future research should include and 
compare different methods, such as face-to-face and computer-based training interventions, to explore any differences in their effectiveness.

\section{Conclusions}

To conclude, we found a positive effect of exposure to numerical training videos on counting, but not on number line knowledge. Our analyses also showed a significant benefit on the children's understanding of cardinality five months after they had received the numerical training, whereas it had no influence on their WM. Our findings confirm the importance of considering videos as a useful way to strengthen early numerical skills in preschool age. Unlike training interventions discussed in the literature, our study focused on an age group not usually considered for intervention studies on children's numerical abilities. We also conducted a follow-up assessment of the children's numerical abilities six months after the end of the numerical training, which showed lasting effects of the intervention on their counting skills and understanding of cardinality. Given the role of numerical skills in predicting individual and collective educational, economic and financial success, our findings may have relevant practical implications. For instance, videos could be a simple and effective way to develop and disseminate training interventions on a large scale, given the popularity and accessibility of video streaming platforms among preschoolers $[67,68,94]$. They could be used to deliver entertaining, targeted and effective interventions in deprived settings where numerical skills are undertrained, and thereby prevent the risk of children developing difficulties and negative attitudes to mathematics as they grow older $[95,96]$.

Author Contributions: Conceptualization, A.C., M.V., C.D.V., S.P. and M.C.P.; methodology, A.C. and M.V.; formal analysis, A.C. and C.D.V.; writing-original draft preparation, A.C., M.V. and S.P.; writing-review and editing, C.D.V. and M.C.P.; supervision, S.P. and M.C.P. All authors have read and agreed to the published version of the manuscript.

Funding: This research received no external funding.

Institutional Review Board Statement: The study was conducted in accordance with the Declaration of Helsinki, and the protocol was approved by the Institutional Review Board of Area Educazione, Università, Ricerca, Cultura e Sport (Prot. n. 16-5/9/2017-7 (1964), 15 February 2017).

Informed Consent Statement: Informed consent was obtained from the parents of each child involved in the study.

Data Availability Statement: The data presented in this study are available on request from the corresponding author. The data are not publicly available due to privacy.

Conflicts of Interest: The authors declare no conflict of interest.

\section{References}

1. Bynner, J.M. Basic skills in adolescents' occupational preparation. Career Dev. Q. 1997, 45, 305-321. [CrossRef]

2. Rivera-Batiz, F.L. Quantitative literacy and the likelihood of employment among young adults in the United States. J. Hum. Resour. 1992, 27, 313-328. [CrossRef]

3. Dougherty, C. Numeracy, literacy and earnings: Evidence from the National Longitudinal Survey of Youth. Econ. Educ. Rev. 2003, 22, 511-521. [CrossRef]

4. Gerardi, K.; Goette, L.; Meier, S. Numerical ability predicts mortgage default. Proc. Natl. Acad. Sci. USA 2013, 110, 11267-11271. [CrossRef] [PubMed]

5. Gross, J.; Hudson, C.; Price, D. The Long Term Costs of Numeracy Difficulties; Every Child a Chance Trust and KPMG: East Sussex, UK, 2009.

6. $\quad$ Barbaresi, W.J.; Katusic, S.K.; Colligan, R.C.; Weaver, A.L.; Jacobsen, S.J. Math learning disorder: Incidence in a population-based birth cohort, 1976-82, Rochester. Minn. Ambul. Pediatr. 2005, 5, 281-289. [CrossRef]

7. Butterworth, B. Foundational numerical capacities and the origins of dyscalculia. In Space, Time and Number in the Brain; Academic Press: London, UK, 2011; pp. 249-265.

8. Shalev, R.S. Prevalence of developmental dyscalculia. In Why Is Math so Hard for Some Children? The Nature and Origins of Mathematical Learning Difficulties and Disabilities; Brookes Publishing: Baltimore, MA, USA, 2007; pp. 49-60. 
9. Shalev, R.S.; Manor, O.; Gross-Tsur, V. Developmental dyscalculia: A prospective six-year follow-up. Dev. Med. Child Neurol. 2005, 47, 121-125. [CrossRef] [PubMed]

10. Duncan, G.J.; Dowsett, C.J.; Claessens, A.; Magnuson, K.; Huston, A.C.; Klebanov, P.; Pagani, L.S.; Feinstein, L.; Engel, M.; Brooks-Gunn, J.; et al. School readiness and later achievement. Dev. Psychol. 2007, 43, 1428-1446. [CrossRef] [PubMed]

11. Gathercole, S.E.; Pickering, S.J.; Knight, C.; Stegmann, Z. Working memory skills and educational attainment: Evidence from national curriculum assessments at 7 and 14 years of age. Appl. Cogn. Psychol. 2004, 18, 1-16. [CrossRef]

12. Kroesbergen, E.H.; Van Luit, J.E.H.; Van Lieshout, E.C.D.M.; Van Loosbroek, E.; Van de Rijt, B.A.M. Individual differences in early numeracy: The role of executive functions and subitizing. J. Psychoeduc. Assess. 2009, 27, 226-236. [CrossRef]

13. Träff, U. The contribution of general cognitive abilities and number abilities to different aspects of mathematics in children. J. Exp. Child Psychol. 2013, 116, 139-156. [CrossRef]

14. Aunola, K.; Leskinen, E.; Lerkkanen, M.K.; Nurmi, J.E. Developmental dynamics of math performance from preschool to grade 2. J. Educ. Psychol. 2004, 96, 699-713. [CrossRef]

15. Aunio, P.; Niemivirta, M. Predicting children's mathematical performance in grade one by early numeracy. Learn. Individ. Differ 2010, 20, 427-435. [CrossRef]

16. Jordan, N.C.; Kaplan, D.; Locuniak, M.N.; Ramineni, C. Predicting first-grade math achievement from developmental number sense trajectories. Learn. Disabil. Res. Pract. 2007, 22, 36-46. [CrossRef]

17. Geary, D.C. Mathematics and learning disabilities. J. Learn. Disabil. 2004, 37, 4-15. [CrossRef]

18. Passolunghi, M.C.; Vercelloni, B.; Schadee, H. The precursors of mathematics learning: Working memory, phonological ability and numerical competence. Cogn. Dev. 2007, 22, 165-184. [CrossRef]

19. Jordan, N.C.; Kaplan, D.; Ramineni, C.; Locuniak, M.N. Early math matters: Kindergarten number competence and later mathematics outcomes. Dev. Psychol. 2009, 45, 850-867. [CrossRef]

20. Martin, R.B.; Cirino, P.T.; Sharp, C.; Barnes, M. Number and counting skills in kindergarten as predictors of grade 1 mathematical skills. Learn. Individ. Differ. 2014, 34, 12-23. [CrossRef]

21. Nguyen, T.; Watts, T.W.; Duncan, G.J.; Clements, D.H.; Sarama, J.S.; Wolfe, C.; Spitler, M.E. Which preschool mathematics competencies are most predictive of fifth grade achievement? Early Child. Res. 2016, 36, 550-560. [CrossRef] [PubMed]

22. Koponen, T.; Aunola, K.; Nurmi, J.E. Verbal counting skill predicts later math performance and difficulties in middle school. Contemp. Educ. Psychol. 2019, 59, 101803. [CrossRef]

23. Gelman, R.; Gallistel, C.R. The Child's Concept of Number; Harvard University Press: Cambridge, MA, USA, 1978.

24. Halberda, J.; Taing, L.; Lidz, J. The development of "most" comprehension and its potential dependence on counting ability in preschoolers. Lang. Learn. Dev. 2008, 4, 99-121. [CrossRef]

25. Le Corre, M.; Carey, S. One, two, three, four, nothing more: An investigation of the conceptual sources of the verbal counting principles. Cognition 2007, 105, 395-438. [CrossRef]

26. Wynn, K. Children's understanding of counting. Cognition 1990, 36, 155-193. [CrossRef]

27. Fuson, K.C. Children's Counting and Concepts of Number; Springer: New York, NY, USA, 1988.

28. Mix, K.S.; Sandhofer, C.M.; Moore, J.A.; Russell, C. Acquisition of the cardinal word principle: The role of input. Early Child. Res. Q. 2012, 27, 274-283. [CrossRef]

29. Paliwal, V.; Baroody, A.J. How best to teach the cardinality principle? Early Child. Res. 2018, 44, 152-160. [CrossRef]

30. Geary, D.C.; vanMarle, K.; Chu, F.W.; Rouder, J.; Hoard, M.K.; Nugent, L. Early conceptual understanding of cardinality predicts superior school-entry number-system knowledge. Psychol. Sci. 2018, 29, 191-205. [CrossRef] [PubMed]

31. Chu, F.W.; Geary, D.C. Early numerical foundations of young children's mathematical development. J. Exp. Child Psychol. 2015, 132, 205-212. [CrossRef]

32. Sarnecka, B.W.; Carey, S. How counting represents number: What children must learn and when they learn it. Cognition 2008, 108, 662-674. [CrossRef]

33. Sarnecka, B.W.; Wright, C.E. The idea of an exact number: Children's understanding of cardinality and equinumerosity. Cogn. Sci. 2013, 37, 1493-1506. [CrossRef]

34. Ansari, D.; Donlan, C.; Thomas, M.S.; Ewing, S.A.; Peen, T.; Karmiloff-Smith, A. What makes counting count? Verbal and visuo-spatial contributions to typical and atypical number development. J. Exp. Child Psychol. 2003, 85, 50-62. [CrossRef]

35. Gallistel, C.R.; Gelman, R. Non-verbal numerical cognition: From reals to integers. Trends Cogn. Sci. 2000, 4, 59-65. [CrossRef]

36. Hubbard, E.M.; Piazza, M.; Pinel, P.; Dehaene, S. Interactions between number and space in parietal cortex. Nat. Rev. Neurosci. 2005, 6, 435-448. [CrossRef]

37. Siegler, R.S. Magnitude knowledge: The common core of numerical development. Dev. Sci. 2016, 19, 341-361. [CrossRef]

38. Schneider, M.; Merz, S.; Stricker, J.; De Smedt, B.; Torbeyns, J.; Verschaffel, L.; Luwel, K. Associations of number line estimation with mathematical competence: A meta-analysis. Child Dev. 2018, 89, 1467-1484. [CrossRef] [PubMed]

39. McLean, J.F.; Hitch, G.H. Working memory impairments in children with specific mathematics learning difficulties. J. Exp. Child Psychol. 1999, 74, 240-260. [CrossRef]

40. Raghubar, K.P.; Barnes, M.A.; Hecht, S.A. Working memory and mathematics: A review of developmental, individual difference, and cognitive approaches. Learn. Individ. Differ. 2010, 20, 110-122. [CrossRef]

41. Baddeley, A. The episodic buffer: A new component of working memory? Trends Cogn. Sci. 2000, 4, 417-423. [CrossRef]

42. Baddeley, A.D. Is working memory still working? Eur. Psychol. 2002, 7, 85-97. [CrossRef] 
43. Baddeley, A.D.; Allen, R.J.; Hitch, G.J. Binding in visual working memory: The role of the episodic buffer. Neuropsychologia 2011, 49, 1393-1400. [CrossRef] [PubMed]

44. Baddeley, A.D.; Hitch, G. Working Memory. In Psychology of Learning and Motivation; Academic Press: New York, NY, USA, 1974; Volume 8, pp. 47-89.

45. Cornoldi, C.; Vecchi, T. Visuo-Spatial Working Memory and Individual Differences; Psychology Press: London, UK, 2003.

46. De Vita, C.; Costa, H.M.; Tomasetto, C.; Passolunghi, M.C. The contributions of working memory domains and processes to early mathematical knowledge between preschool and first grade. Psychol. Res. 2021, 1-15. [CrossRef] [PubMed]

47. De Smedt, B.; Janssen, R.; Bouwens, K.; Verschaffel, L.; Boets, B.; Ghesquière, P. Working memory and individual differences in mathematics achievement: A longitudinal study from first grade to second grade. J. Exp. Child Psychol. 2009, 103, 186-201. [CrossRef]

48. Menon, V. Working memory in children's math learning and its disruption in dyscalculia. Curr. Opin. Behav. Sci. 2016, 10, 125-132 [CrossRef]

49. Passolunghi, M.C.; Siegel, L.S. Working memory and access to numerical information in children with disability in mathematics. J. Exp. Child Psychol. 2004, 88, 348-367. [CrossRef] [PubMed]

50. Fanari, R.; Meloni, C.; Massidda, D. Visual and spatial working memory abilities predict early math skills: A longitudinal study. Front. Psychol. 2019, 10, 2460. [CrossRef]

51. Friso-Van den Bos, I.; Van der Ven, S.H.; Kroesbergen, E.H.; Van Luit, J.E. Working memory and mathematics in primary school children: A meta-analysis. Educ. Res. Rev. 2013, 10, 29-44. [CrossRef]

52. Rasmussen, C.; Bisanz, J. Representation and working memory in early arithmetic. J. Exp. Child Psychol. 2005, 91, 137-157. [CrossRef]

53. Whyte, J.C.; Bull, R. Number games, magnitude representation, and basic number skills in preschoolers. Dev. Psychol. 2008, 44, 588-596. [CrossRef] [PubMed]

54. Kyttälä, M.; Kanerva, K.; Kroesbergen, E. Training counting skills and working memory in preschool. Scand. J. Psychol. 2015, 56, 363-370. [CrossRef] [PubMed]

55. Ramani, G.B.; Siegler, R.S. Promoting broad and stable improvements in low-income children's numerical knowledge through playing number board games. Child Dev. 2008, 79, 375-394. [CrossRef]

56. Passolunghi, M.C.; Costa, H.M. Working memory and early numeracy training in preschool children. Child Neuropsychol. 2016, 22, 81-98. [CrossRef] [PubMed]

57. Schacter, J.; Jo, B. Improving low-income preschoolers mathematics achievement with Math Shelf, a preschool tablet computer curriculum. Comput. Hum. Behav. 2016, 55, 223-229. [CrossRef]

58. Young-Loveridge, J.M. Effects on early numeracy of a program using number books and games. Early Child. Res. Q. 2004, 19, 82-98. [CrossRef]

59. Sella, F.; Tressoldi, P.; Lucangeli, D.; Zorzi, M. Training numerical skills with the adaptive videogame "The Number Race": A randomized controlled trial on preschoolers. Trends Neurosci. Educ. 2016, 5, 20-29. [CrossRef]

60. Kroesbergen, E.H.; Van't Noordende, J.E.; Kolkman, M.E. Number sense in low-performing kindergarten children: Effects of a working memory and an early math training. In Reading, Writing, Mathematics and the Developing Brain: Listening to Many Voices; Springer: Dordrecht, The Netherlands, 2012; pp. 295-313.

61. Melby-Lervåg, M.; Hulme, C. Is working memory training effective? A meta-analytic review. Dev. Psychol. 2013, 49, $270-291$. [CrossRef] [PubMed]

62. Melby-Lervåg, M.; Redick, T.S.; Hulme, C. Working memory training does not improve performance on measures of intelligence or other measures of "far transfer" evidence from a meta-analytic review. Perspect. Psychol. Sci. 2016, 11, 512-534. [CrossRef]

63. Thorell, L.B.; Lindqvist, S.; Bergman Nutley, S.; Bohlin, G.; Klingberg, T. Training and transfer effects of executive functions in preschool children. Dev. Sci. 2009, 12, 106-113. [CrossRef] [PubMed]

64. Gade, M.; Zoelch, C.; Seitz-Stein, K. Training of visual-spatial working memory in preschool children. Adv. Cogn. Psychol. 2017, 13, 177-187. [PubMed]

65. Siegler, R.S.; Ramani, G.B. Playing linear number board games-But not circular ones-Improves low-income preschoolers' numerical understanding. J. Educ. Psychol. 2009, 101, 545-560. [CrossRef]

66. Siegler, R.S.; Booth, J. Development of numerical estimation in young children. Child Dev. 2004, 75, 428-444. [CrossRef]

67. Rideout, V.; Robb, M.B. The Common Sense Census: Media Use by Kids Age Zero to Eight; Common Sense Media: San Francisco, CA, USA, 2020 .

68. Marsh, J.; Law, L.; Lahmar, J.; Yamada-Rice, D.; Parry, B.; Scott, F.; Robinson, P.; Nutbrown, B.; Scholey, E.; Baldi, P.; et al. Social Media, Television and Children; University of Sheffield: Sheffield, UK, 2019.

69. DeLoache, J.S.; Chiong, C.; Sherman, K.; Islam, N.; Vanderborght, M.; Troseth, G.L.; Strouse, G.A.; O'Doherty, K. Do babies learn from baby media? Psychol. Sci. 2010, 21, 1570-1574. [CrossRef] [PubMed]

70. Anderson, D.R.; Huston, A.C.; Schmitt, K.L.; Linebarger, D.L.; Wright, J.C.; Larson, R. Early childhood television viewing and adolescent behavior: The recontact study. Monogr. Soc. Res. Child. 2001, 66, 1-154. [CrossRef]

71. Fisch, S.M.; Truglio, R.T.; Cole, C.F. The impact of Sesame Street on preschool children: A review and synthesis of 30 years' research. Media Psychol. 1999, 1, 165-190. [CrossRef] 
72. Rice, M.L.; Huston, A.C.; Truglio, R.; Wright, J.C. Words from "Sesame Street": Learning vocabulary while viewing. Dev. Psychol. 1990, 26, 421-428. [CrossRef]

73. Troseth, G.L. Is it life or is it Memorex? Video as a representation of reality. Dev. Rev. 2010, 30, 155-175. [CrossRef]

74. Ball, S.; Bogatz, G.A. A Summary of the Major Findings in "The First Year of Sesame Street: An Evaluation"; Educational Testing Service: Princeton, NJ, USA, 1970; pp. 1-33.

75. Bogatz, G.A.; Ball, S. The Second Year of Sesame Street: A Continuing Evaluation: A Report to the Children's Television Workshop; Educational Testing Service: Princeton, NJ, USA, 1971; Volume 1, pp. 1-310.

76. Linebarger, D.L.; Walker, D. Infants' and toddlers' television viewing and language outcomes. Am. Behav. Sci. 2005, 48, 624-645. [CrossRef]

77. Mares, M.L.; Pan, Z. Effects of Sesame Street: A meta-analysis of children's learning in 15 countries. J. Appl. Dev. Psychol. 2013, 34, 140-151. [CrossRef]

78. Lauricella, A.R.; Gola, A.A.H.; Calvert, S.L. Toddlers' learning from socially meaningful video characters. Media Psychol. 2011, 14, 216-232. [CrossRef]

79. Aladé, F.; Lauricella, A.R.; Beaudoin-Ryan, L.; Wartella, E. Measuring with Murray: Touchscreen technology and preschoolers' STEM learning. Comput. Hum. Behav. 2016, 62, 433-441. [CrossRef]

80. Schroeder, E.L.; Kirkorian, H.L. When seeing is better than doing: Preschoolers' transfer of STEM skills using touchscreen games Front. Psychol. 2016, 7, 1377. [CrossRef]

81. Geary, D.C.; vanMarle, K. Young children's core symbolic and nonsymbolic quantitative knowledge in the prediction of later mathematics achievement. Dev. Psychol. 2016, 52, 2130-2144. [CrossRef]

82. Wechsler, D. Wechsler Preschool and Primary Scale of Intelligence, 4th ed.; The Psychological Corporation: San Antonio, TX, USA, 2012.

83. Gugliotta, M.; Bisiacchi, P.S.; Cendron, M.; Tressoldi, P.M.; Vio, C. BVN 12-18: Batteria di Valutazione Neuropsicologica per L'adolescenza; Erickson: Trento, Italy, 2009.

84. Lanfranchi, S.; Cornoldi, C.; Vianello, R. Verbal and visuospatial working memory deficits in children with Down syndrome. Am. J. Ment. Retard. 2004, 109, 456-466. [CrossRef]

85. Molin, A.; Poli, S.; Lucangeli, D. BIN 4-6. Batteria per la Valutazione dell'intelligenza Numerica in Bambini dai 4 a 6 anni; Erikson: Trento, Italy, 2007.

86. Laski, E.V.; Siegler, R.S. Is 27 a big number? Correlational and causal connections among numerical categorization, number line estimation, and numerical magnitude comparison. Child Dev. 2007, 78, 1723-1743. [CrossRef]

87. Cohen, J. Statistical Power Analysis for the Behavioral Sciences, 2nd ed.; Lawrence Erlbaum Associates Publishers: Mahwah, NJ, USA, 1988; pp. 4-579.

88. Alloway, T.P.; Bibile, V.; Lau, G. Computerized working memory training: Can it lead to gains in cognitive skills in students? Comput. Hum. Behav. 2013, 29, 632-638. [CrossRef]

89. Brehmer, Y.; Westerberg, H.; Bäckman, L. Working-memory training in younger and older adults: Training gains, transfer, and maintenance. Front. Hum. Neurosci. 2012, 6, 63. [CrossRef] [PubMed]

90. Pellizzoni, S.; Apuzzo, G.M.; De Vita, C.; Agostini, T.; Passolunghi, M.C. Evaluation and training of executive functions in genocide survivors. The case of Yazidi children. Dev. Sci. 2019, 22, e12798. [CrossRef]

91. Raghubar, K.P.; Barnes, M.A. Early numeracy skills in preschool-aged children: A review of neurocognitive findings and implications for assessment and intervention. Clin. Neuropsychol. 2017, 31, 329-351. [CrossRef] [PubMed]

92. Van De Rijt, B.A.; Van Luit, J.E. Milestones in the development of infant numeracy. Scand. J. Psychol. 1999, 40, 65-71. [CrossRef]

93. Xu, C.; Burr, S.D.L.; Douglas, H.; Susperreguy, M.I.; LeFevre, J.A. Number line development of Chilean children from preschool to the end of kindergarten. J. Exp. Child Psychol. 2021, 208, 105144. [CrossRef]

94. Burroughs, B. YouTube kids: The app economy and mobile parenting. Soc. Media Soc. 2017, 3. [CrossRef]

95. Caviola, S.; Toffalini, E.; Giofrè, D.; Ruiz, J.M.; Szúcs, D.; Mammarella, I.C. Math performance and academic anxiety forms, from sociodemographic to cognitive aspects: A meta-analysis on 906,311 participants. Educ. Psychol. Rev. 2021, 1-37. [CrossRef]

96. Pellizzoni, S.; Cargnelutti, E.; Cuder, A.; Passolunghi, M.C. The interplay between math anxiety and working memory on math performance: A longitudinal study. Ann. N. Y. Acad. Sci. 2021, 1-13. [CrossRef] 